\title{
The 3D Jumping Technical Analysis of Long Jump Athletes Based on the Statistics
}

\author{
Baozhai $\mathrm{Li}^{1}$, Xue Ding ${ }^{2}$, Xincheng Shi ${ }^{3}$ \\ ${ }^{1}$ Department of Physical Education, Hebei Institute of Physical Education, Shijiazhuang, China \\ li_baozhai@126.com \\ ${ }^{2}$ Foundation department, Heibei United University Qian'an College, Qianan, China \\ ${ }^{3}$ Student Work Department, Heibei United University Qian'an College \\ Qianan, China
}

Keywords: kinematic analysis; statistical analysis; treading and jumping

Abstract. Treading and jumping is the hardest and most important stage in long jump technique. From the point of mechanics, Treading and jumping can be divided into two parts of tread and jump. Jumping task is in rapid run-up conditions, through the reasonable jumping action to change human body movement direction, the athletes get an appropriate take-off angle of body gravity and the initial jump velocity. So, the stand or fall of jumping skills of the athletes themselves is one of the important symbols of its movement level. The essential to improve the performance of long jump is completing jumping technique. This paper discusses the influence factors of treading and jumping, from the angle of statistical computing science, and provide theoretical basis for athletes training.

\section{The research object}

In the paper, the research object are long jump athletes, who participate in a track and field competition, we take the last two steps approach and take-off technology of the first six athletes, athletes basic situation such as table 1 .

\begin{tabular}{|c|c|l|l|l|}
\hline Name & Born & $\begin{array}{c}\text { Height( } \\
\mathbf{m})\end{array}$ & $\begin{array}{c}\text { Weight( } \\
\text { kg) }\end{array}$ & $\begin{array}{c}\text { Registration } \\
\text { results (m) }\end{array}$ \\
\hline $\boldsymbol{A}$ & 90.04 & 1.75 & 67 & 6.33 \\
\hline $\boldsymbol{B}$ & 94.08 & 1.77 & 63 & 6.12 \\
\hline $\boldsymbol{C}$ & 91.01 & 1.78 & 64 & 6.37 \\
\hline $\boldsymbol{D}$ & 88.10 & 1.71 & 61 & 5.90 \\
\hline $\boldsymbol{E}$ & 89.01 & 1.70 & 57 & 6.18 \\
\hline $\boldsymbol{F}$ & 80.12 & 1.76 & 56 & 5.92 \\
\hline
\end{tabular}

\section{The research methods}

This paper uses the mathematical statistics method to research, through the experiment to get relevant motion parameters. Using Microsoft Office 2003 Excel and SPSS13.0 statistical package process the data. Using the relevant mathematical formula to calculate and statistics and analysis for the kinematics parameters, if $P<0.01$, we think that has very significant difference, if $P<0.05$, we think that has significant difference.

\section{Kinematics statistical analysis of jumping technology}

A. Jumping time analysis 
TABLE II. THE EACH SECTION TIME STATISTICS ANALYSIS OF SIX ATHLETES IN JUMPING PHASE

\begin{tabular}{|c|l|l|l|l|}
\hline Name & Buffer time (T1) & Transformation time (T2) & tic stretch time (T3) & Jumping time (T4) \\
\hline $\boldsymbol{A}$ & 0.041 & 0.041 & 0.041 & 0.121 \\
\hline $\boldsymbol{B}$ & 0.021 & 0.041 & 0.041 & 0.101 \\
\hline $\boldsymbol{C}$ & 0.041 & 0.041 & 0.061 & 0.101 \\
\hline $\boldsymbol{D}$ & 0.041 & 0.021 & 0.041 & 0.121 \\
\hline $\boldsymbol{E}$ & 0.041 & 0.041 & 0.041 & 0.121 \\
\hline $\boldsymbol{F}$ & 0.061 & 0.041 & 0.041 \\
\hline average & 0.041 & 0.037 & 0.141 \\
\hline
\end{tabular}

Among of them, the T1 is the athlete's takeoff buffer period; T2 is the athlete's takeoff transformation period; T3 is athlete pedal stretch time.

TABLE III. THE STATISTICAL ANALYSIS OF CORRELATION COEFFICIENT FOR EACH PERIOD AND PERFORMANCE OF ATHLETES JUMPING

\begin{tabular}{|c|c|c|c|c|c|}
\hline Time & buffer & \multicolumn{2}{|c|}{$\begin{array}{c}\text { transformatio } \\
\text { n }\end{array}$} & tic stretch & $\begin{array}{l}\text { the entire } \\
\text { section }\end{array}$ \\
\hline $\boldsymbol{r}$ & -0.323 & \multicolumn{2}{|l|}{0.745} & 0.044 & 0.233 \\
\hline$p$ & $>0.05$ & \multicolumn{2}{|l|}{$<0.05$} & $>0.05$ & $>0.05$ \\
\hline \multicolumn{6}{|c|}{ EACH TIME RATIO TABLE OF THE ATHLETE'S TAKEOFF } \\
\hline \multicolumn{2}{|c|}{ Category } & $\begin{array}{l}\text { buffer } \\
\text { time }\end{array}$ & \multicolumn{2}{|c|}{$\begin{array}{c}\text { transformation } \\
\text { period }\end{array}$} & $\begin{array}{c}\text { tic stretch } \\
\text { time }\end{array}$ \\
\hline \multicolumn{2}{|c|}{$\begin{array}{l}\text { ratio } \\
(\%)\end{array}$} & $4.3 \%$ & $31.7 \%$ & & $34.3 \%$ \\
\hline
\end{tabular}

From table 2, 3, 4, we can see, the correlation coefficient of $T_{2}$ with the grade of the athlete is the highest ( $R=0.745$ ), time ratio reflects the athlete's sports ability of long jump athlete, but in this paper the result of $T_{2}$ is minimum, this suggests that their lower limbs strength has some shortage, and special strength is not enough, $T_{1}$ is the ability that the athlete body to pedal reaction conversion into jumping power level, $T_{3}$ is the ability that the long jump athletes takeoff leg stop as soon as possible, the ratio of $T_{1}$ and $T_{3}$ is equal, on the whole, they have a lot of potential in theirs rapid dive ability, the ratio for $\mathrm{B}$ athletes is the best during each scale, so B athletes can achieve better result. If this phrase can be improved for $\mathrm{A}$ athlete and $\mathrm{C}$ athletes can normal dive, they all can achieve better results.

B. The statistical analysis of the plate knee Angle, two leg Angle, circle Angle

\begin{tabular}{|c|c|c|c|c|}
\hline Name & $\begin{array}{c}\text { Landing } \\
\text { angle }\end{array}$ & $\begin{array}{c}\begin{array}{c}\text { Pedal } \\
\text { angle }\end{array} \\
\end{array}$ & $\begin{array}{c}\text { Take off } \\
\text { angle }\end{array}$ & $\begin{array}{c}\text { Sector } \\
\text { angle }\end{array}$ \\
\hline$A$ & 55.81 & 72.51 & 17.50 & 51.68 \\
\hline B & 63.45 & 77.56 & 12.44 & 38.99 \\
\hline$C$ & 58.08 & $\begin{array}{l}76.38 \\
\end{array}$ & 13.62 & 45.54 \\
\hline$D$ & 56.67 & 73.69 & 16.31 & 50.63 \\
\hline$E$ & 58.04 & 74.64 & 15.36 & 47.32 \\
\hline$F$ & 55.88 & 73.73 & 16.27 & 50.39 \\
\hline$X$ & 57.99 & 74.75 & 15.25 & 47.43 \\
\hline$S$ & 2.86 & 1.89 & 1.86 & 4.73 \\
\hline
\end{tabular}

As you can see from table 5, 6 athletes takeoff angle is $57.98 \pm 2.85^{\circ}$, and did not reach Fairbanks $\left(64-69^{0}\right)$ model, some scholars study shows: some of the best athletes jump landing scale is generally $63.14^{0}$, the average score of 6 athletes is close to this value, but the difference is about $5.15^{0}$ ( $\left.\mathrm{T}=-4.419, \mathrm{P}<0.01\right)$, this is a very significant difference. landing scale of athlete $\mathrm{B}$ is the biggest $\left(63.45^{\circ}\right)$, the main reason for this result is that the athlete $\mathrm{B}$ can takeoff in a very short time, and has good tension time index. In the same running conditions, the take-off leg landing angle and climb telescopic decided to jump the force direction and time. The jump foot extension (the angle is too small), will make the stop power increase and prolong action time, this will make the athlete's body is too backward, beginning as early as to stretch, take-off angle is too large, jumping too high, resulting in the loss of horizontal velocity is too big. Takeoff leg landing is too near (the angle is too large). 
With the considerations of take-off time, 6 athletes takeoff average time is $0.177 \mathrm{~s}$ and There is no difference with $0.08-0.14 s$ ( $\mathrm{P}>0.05$ ), individual athletes takeoff time is $0.10 \mathrm{~s}$, it has the rapid take-off speed.

C. The statistical analysis of pedal floor horizontal speed, jumping off speed, take-off angle TABLE VI. TRANSFORMATION RATE OF HORIZONTAL SPEED AND FLIGHT ANGLE (M/s)

\begin{tabular}{|c|c|c|c|c|}
\hline & \multirow{2}{*}{$\begin{array}{l}\text { average speed of Pedal } \\
\text { down }(\mathrm{m} / \mathrm{s})\end{array}$} & \multicolumn{2}{|c|}{ average speed of jumping off the ground $(\mathrm{m} / \mathrm{s})$} & \multirow{2}{*}{$\begin{array}{l}\text { Speed loss } \\
\quad(\mathbf{m} / \mathbf{s})\end{array}$} \\
\hline & & horizontal speed & Vertical speed & \\
\hline$A$ & 9.38 & 8.04 & 2.88 & 1.36 \\
\hline$B$ & 9.97 & 7.33 & 2.76 & 2.63 \\
\hline$C$ & 10.62 & 9.13 & 3.27 & 1.47 \\
\hline$D$ & 10.13 & 9.04 & 3.23 & 1.10 \\
\hline$E$ & 9.48 & 7.82 & 2.89 & 1.66 \\
\hline$F$ & 8.43 & 7.51 & 2.75 & 0.94 \\
\hline average & 9.77 & 8.36 & 3.11 & 1.39 \\
\hline $\begin{array}{l}\text { Standard } \\
\text { deviation }\end{array}$ & \pm 0.66 & \pm 0.67 & \pm 0.21 & \pm 0.54 \\
\hline
\end{tabular}

The most range of the velocity loss of the 6 athletes is $1.65 \pm 0.42 \mathrm{~m} / \mathrm{s}$, but the loss velocity of athlete $\mathrm{C}$ is $2.64 \mathrm{~m} / \mathrm{s}$, it is far greater than this value, probably because of its fast run-up and take-off is not synchronous with run-up speed capability. This paper discovers that our country athlete's have an ideal vertical take-off speed, but the horizontal speed loss is too large, therefore, in our country, we must improve training method, when we improve the athletes absolute speed level at the same time.

D. The kinematics analysis of swing leg

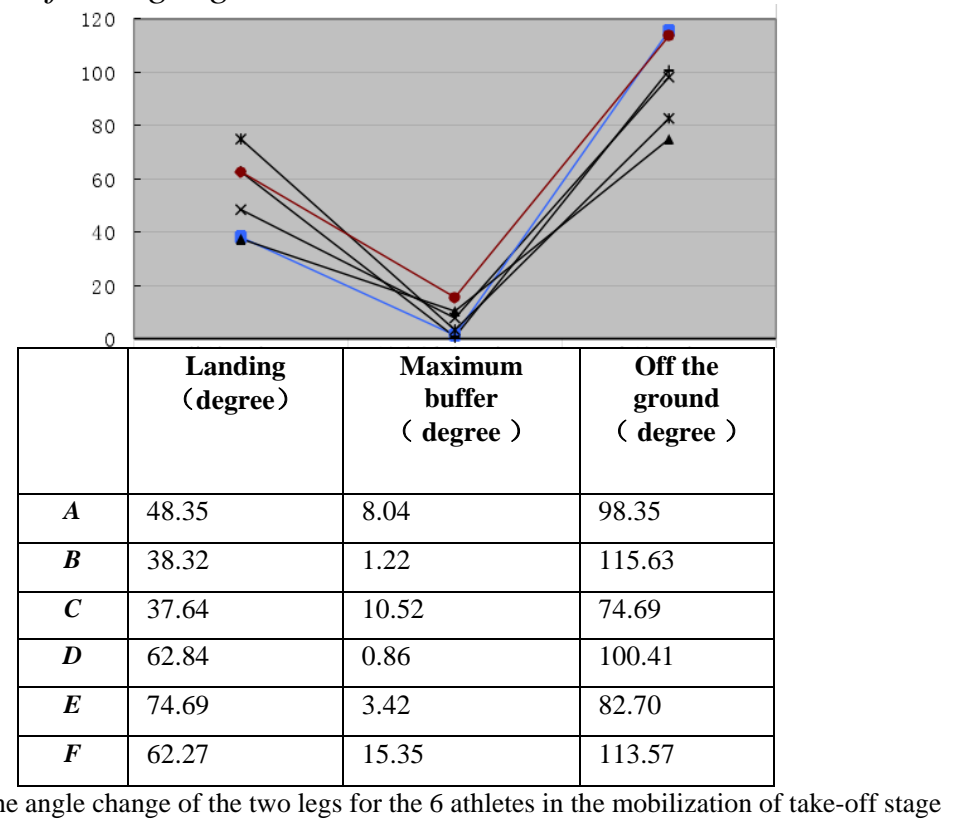

Figure 1. The angle change of the two legs for the 6 athletes in the mobilization of take-off stage

Here you can see that, $\mathrm{C}$ athletes' leg angle within a reasonable range relative to the other player is smaller, pedal actively, free consciousness is strong to swing the leg, and the knee joint using reasonably, reduces the resistance loss of the run-up speed and the take-off. It shows its good technical and consciousness. Athletes jumping skills may have some shortcomings, such as pedal technique may cause adverse effects.

If the athlete attention swing time away from the ground, his jump effect will be better. The angle is the minimum of athlete $C$ when he pedal board, but the effect is not ideal, the reason may be the last step of the approach is too long. In order to reduce the loss of horizontal velocity, six athletes in the pedal should actively promote the swing of swing leg, thus to achieve the best results. Long jump athletes to make full and rational use of the swinging leg technology, they can appropriate to strengthen the training, so as to improve their techniques in long jump.

As you can see, knee angle of the athlete $\mathrm{E}$ is 159.78 degrees on the pedal plate moment, and the stage of the buffer time is 0.079 seconds, in the pedal moment, athlete's vertical pressure increase, due to the reduction of knee angle contributes to jump resistance to reduce, helps the body center of gravity to move forward, thus it is beneficial to athletes in the jumping when the full use of its 
approach, reduce the take-off time, reduce speed loss rate. The knee angle too large may be caused by physical and distance judgment which is not enough. In the actual teaching and training we must train swinging amplitude of the athletes from the maximum buffer to off the ground stage, so as to improve the athletes' takeoff effect.

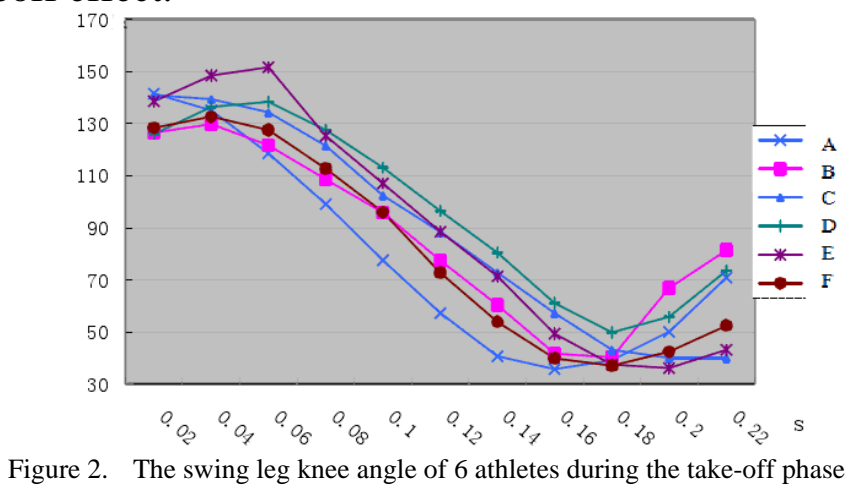

\section{Conclusions}

The above analysis shows, knee joint and leg angle of Elite Long Jumpers is better at pedal moment, but because consciousness of swing of swing leg of some players is not strong, so that the pedal effect weakened; some athletes takeoff time is reasonable, but the buffer time is too long, the distribution is not reasonable, affect the final take-off effect; through this research found that there is no significant difference of instant take-off vertical speed between the Chinese athletes and excellent athletes in the world; but the jumping angle have significant differences with the world elite athletes, so jumping angle is still influenced Chinese long-jump achievement.

Suggestions for athletes in the approach to improve the speed at the same time, focus on strengthening the knee under high speed eccentric contraction ability, appropriately increase the swinging of the swinging leg; although the take-off angle for the athletes to improve performance is important, but we can not lost the horizontal velocity, which is to have the order reversed.

\section{References}

[1] Zhang Junxia, Liu Shengjie kinematics analysis of take-off stage parameters in ten games [J]. Journal of Physical Education Institute of Shanxi Normal University, 2009 (6), Volume 24 (2), 116-118.

[2] Yu Xiaoming. Analysis of evaluation index for Long jump take-off effect [J]. Journal of Shanghai Institute of Physical Education, 1999 (2).

[3] Liu ya. the analysis of kinematic parameters of female long jump athletes in China at the last step and take-off technique of [D]. Shanxi University, 2005 (6), 8-10.

[4] Ma Yongzhan, Fang Ailian. Kinematic comparative study on Take-off Technique of Chinese Elite Long Jumper [J]. Chinese sports science and technology, 2001, 32 (7).

[5] Yu Xiaoming evaluation index analysis of take-off effect [J]. Journal of Shanghai Institute of Physical Education, 1999 (2).

[6] Peng Jinzhou, Sun Sizhe. Kinematics and dynamics analysis of take-off vertical velocity generating mechanism [J]. Beijing sports science and technology, 2007 (1).

[7] Xu Shuhai, Zheng Heping. Excellent jumpers take-off technique characteristics [J]. Journal of Xi'an Physical Education University, 1996, (13).

[8] Lv Xianli, Zhang Ni. Research on the biomechanics of long jump technique (J). Journal of Ankang Teachers College, 2006, 18 (5). 